\title{
THE ANALYSIS OF STUDENTS' STRESSED SYLLABLES MASTERY AT SIXTH SEMESTER OF TBI IN IAIN PADANGSIDIMPUAN
}

\author{
By: Dr. Erawadi, M.Ag., Hamka, M.Hum., \\ and Fitri Juliana Lubis
}

\begin{abstract}
$\underline{\text { Abstrak }}$
Penelitian ini membahas tentang analisis penguasaan suku kata siswa yang menekankan pada semester enam TBI di IAIN Padangsidimpuan. Para siswa masih mengalami kesulitan dalam penguasaan suku kata yang tertekan. Tujuan dari penelitian ini adalah untuk mendeskripsikan penguasaan suku kata yang menekankan siswa pada semester enam TBI di IAIN Padangsidimpuan, untuk menemukan kesulitan penguasaan suku kata yang menekankan siswa pada semester enam TBI di IAIN Padangsidimpuan, dan menemukan solusi guru untuk mengatasi kesulitan siswa. dalam penguasaan suku kata yang tertekan pada semester enam TBI di IAIN Padangsidimpuan. Penelitian dilakukan dengan pendekatan kualitatif dan deskriptif. Penelitian dimulai pada bulan Maret 2017 sampai April 2017 di IAIN Padangsidimpuan. Sumber data untuk penelitian ini adalah siswa semester enam di TBI di IAIN Padangsidimpuan sebagai sumber utama dan dosen Pengucapan sebagai sumber sekunder. Ada 2 instrumen dalam mengumpulkan data, ada tes dan wawancara. Data diolah dan dianalisis dengan proses kualitatif. Berdasarkan hasil penelitian, peneliti menemukan bahwa penguasaan suku kata siswa pada semester enam TBI di IAIN Padangsidimpuan adalah 68,92\% dan dapat dikategorikan dengan baik. Kesulitan siswa sulit untuk membedakan onset dan struktur coda, sulit dianalisis kata yang memiliki banyak suku kata, dan sulit di transkrip kata. Alasan masalah siswa dalam penguasaan suku kata yang ditekankan pada semester enam TBI di IAIN Padangsidimpuan adalah bahwa siswa memiliki masalah dalam transkripsi terutama di inti (bunyi vokal), kata-kata tersebut tidak dapat menuliskan sebuah kata karena kurang dalam latihan, motivasi rendah dan Tak peduli kapan guru menjelaskan pokok pembicaraan. Upaya tersebut adalah siswa harus meninjau pelajaran tentang fonem terutama dalam vokal dan konsonan berdasarkan standar bahasa Inggris, sehingga tidak bingung.
\end{abstract}

Key words: Stressed Syllable and Mastery

\section{A. Background}

Pronunciation is a set of habits of producing sounds. The habit of producing a sound is acquired by repeating it over and over again and by being corrected when it is pronounced wrongly. Having good pronunciation skills is an 
important part of every ESL (English Second Language) students' ability to communicate in English.

Then, stress is a supra segmental feature of utterances. It applies not to individual vowels and consonants but to whole syllables whatever they might be. Stressed is the way of sounds (s) in a word with reference to syllabification. Stressed syllable us be heavy while unstressed syllable may be light: any stressed syllable, whether it is a monosyllable or part of polysyllabic word, must have a complex rhyme (that is, a rhyme containing at least two X-position). English and other Germanic language make far more use of differences in stress than do most of the languages of the world. In many languages the position of the stress on the first syllable, irrespective of the number of the syllables in the word. In polish and Swahili, the stress is usually on the penultimate syllable. In some language stress is not a property of the word at all. All the syllables in a French word are about equally stressed. The only increase in stress that occurs in French comes on the last syllable of the phrase. ${ }^{1}$

The syllable is a very important unit. Most people seem to believed that, even if they cannot defined what a syllable is, they can count how many syllables there are in a given word or sentences. If they are asked to do this they often tap their finger as they count, which illustrates the syllable importance in the rhythm of speech. As a matter of fact, if one tries the experiment of asking English speakers to count the syllable in, say a recorded sentences, there is often a considerable amount of disagreement. However, in IAIN Padangsidimpuan have found that many students still have difficulties in stressed syllables mastery. They difficulty in deciding how many syllables a given word of their language contains, they have difficulties count how many syllable in a word, they still confuse transcript the English word and determine place of onset, nucleus and coda in syllable.

Based on the explanation and problems above, the researcher interest in conducting the research with title "The Analysis of Students' Stressed Syllables Mastery at Sixth Semester of TBI in IAIN Padangsidimpuan".

${ }^{1}$ Francis Katamba, An Introduction to Phonology, (London and New York: Chee Leong Press Sdh., Bhd, 1992), p. 153. 


\section{B. The Formulation of the Problem}

Based on the above background and focus of the problem, the researcher formulated the problems of the research as follow:

1. How are the students' stressed syllables mastery at sixth semester of TBI in IAIN Padangsidimpuan?

2. What are students' diffiiculties in stressed syllables mastery at sixth semester of TBI in IAIN Padangsidimpuan?

3. What are teachers solution to overcome students difficulties in stressed syllables mastery at sixth semester of TBI in IAIN Padangsidimpuan?

\section{The Theoretical Description}

\section{The Syllable}

\section{a. Defenition of the syllable}

The syllable is a very important unit. The units the sections into which words are divided while pronouncing them. Each sound which constitutes a peak of prominence is said syllabic. ${ }^{2}$ The syllable is a units of pronunciation consisting of a vowel alone or of a vowel with one or more consonant. A vowel is the nucleus a consonant a marginal element in the syllable, that is, a consonant either at the beginning of a syllable is called initial consonant. Based on the definition above the researcher concludes that syllable is part of element sound in a word consist of vowels and consonants. It is used to identify how a word is sounded with reference to phonetics symbols. Syllable are usually described as consisting of a centre which little or no obstruction to airflow and which sounds comparatively loud; before and after this centre(that is, at the beginning and end of the syllable), there will be greater obstruction to airflow and/ or less loud sound.

We will look at some examples according to Peter Roach in his book English phonetics and phonology:

\footnotetext{
${ }^{2}$ Daniel Jones, An Outline of English Phonetics, (Cambridge: University Press, 1975), p. 55.
} 
1) What we might call a minimum syllable would be a single vowel in isolation, e.g. the words 'are' a:, 'or' o:, 'err' 3:. These are preceded and followed by silence. Isolated sounds such as $\mathrm{m}$, which we sometimes produce to indicate agreement, or $\int$, to ask for silence, must also be regarded as syllable.

2) Some syllables have an onset (that is, they have more than just silence preceding the centre of the syllable):

$$
\text { 'bar' ba: 'key'ki: 'more' mo: }
$$

3) Syllable may have no onset but have a coda:

$$
\text { 'am' æm 'ought' o:t 'ease'i:z }
$$

4) Some syllables have onset and coda:

$$
\text { 'run' rın 'sat'sæt 'fill' fil. }{ }^{3}
$$

From the example above the researcher can conclude that not every syllable have onset and coda, but also only have onset but have no coda. Then, some syllables have no onset but have coda.

\section{b. The structure of the English Syllable}

The structure of a syllable is onset, rhyme, nucleus, and coda. The only obligatory element is the syllable nucleus, normally a vowel. The syllable onset is an optional element, as is the syllable coda. Therefore define a vowel as a speech sound which function as the syllable nucleus. A consonant is a speech sounds which typically occurs at the coda of the syllable. ${ }^{4}$ The research can conclude the structure of the syllable are onset, rhyme, nucleus, and coda, obligatory elements is nucleus that is a vowel. This structure can help to identifying the word to phonetics symbols.

One of the structure of the syllable is onset. Where onset is the initial consonant before nucleus or vowel. If the syllable begins with one consonant, that initial consonant may be any consonant phoneme, such as: 'Deep' di:p, 'Get' g3t, 'Back' bæk, 'You' ju:, 'Car' ka:.

\footnotetext{
${ }^{3}$ Peter Roach, English Phonetic and Phonology :a Practical Course (New York: Cambridge University Press, 1983), p. 70-71.

${ }^{4}$ Beverly Collins and Inger M. Moes, Practical Phonetics and Phonology (London and New York: Roudledge, 2009), p. 73-74.
} 
When we have two or more consonant together call them a consonant cluster. ${ }^{5}$ The firs consonant called pre- initial consonant the other consonant is the initial consonant. Example one sort is composed of followed by one of a small set of consonants. Such as: 'Sway' swei, 'Smoke' smork, 'String' stin. The $\mathrm{s}$ in these cluster is called the preinitial consonant and the other consonant ( $\mathrm{w}, \mathrm{m}, \mathrm{t}$ in the above example) is called initial consonant.

Then, when we look at three consonant cluster we can recognize a clear relationship between them, such as: 'Split' split, 'Stream' stri:m, 'Square' skweə. The $\mathrm{s}$ is the pre- initial consonant, the $\mathrm{p}, \mathrm{t}$, and $\mathrm{k}$ that follow $\mathrm{s}$ in the three example words are the initial consonant and the $1, \mathrm{r}$ and $\mathrm{w}$ are post-initial.

Then, other structure of the syllable is coda, where coda is the consonants at the end of a word. If there is one consonant only, this is called final consonant. Any consonant may be a final consonant except $\mathrm{h}$, $\mathrm{r}, \mathrm{w}, \mathrm{j}$. There are two sorts of two consonant final cluster, one being a final consonant preceded by a pre-final consonant and the other a final consonant followed by a post-final consonant. The pre-final consonants form a small set: $\mathrm{m}, \mathrm{n}, \mathrm{\eta}, \mathrm{l}$, s, we can see this in 'Bump' bımp, 'Bent' bent, 'Bank' bænk, 'Belt' belt, 'Ask' a:sk. The post final consonant also form a small set: s, z, t, d, $\Theta$, example words are 'Bets' bets, 'Eighth' eitӨ.

There are two types of final three consonant clusters, first is pre final plus final plus post final, such as in the following table. ${ }^{6}$ It is three consonant clusters.

\begin{tabular}{|l|c|c|c|}
\hline & Pre final & Final & Post final \\
\hline 'helped' he & $\mathrm{l}$ & $\mathrm{p}$ & $\mathrm{t}$ \\
\hline 'banks' bæ & $\mathrm{n}$ & $\mathrm{k}$ & $\mathrm{s}$ \\
\hline 'Bonds' bo & $\mathrm{n}$ & $\mathrm{d}$ & $\mathrm{z}$ \\
\hline 'twelfth' twe & $\mathrm{l}$ & $\mathrm{f}$ & $\Theta$ \\
\hline
\end{tabular}

\footnotetext{
${ }^{5}$ Peter Roach, English Phonetics And Phonology, (New York: Cambridge University Press, 2000), p. 71.

${ }^{6}$ Ibid., p. 75.
} 
The second type shown that more than one post final consonant can occur in small cluster: final plus post final 1 plus post final 2. Post final 2 is again one of $s, z, t, d, \Theta$. Such as in the following table:

\begin{tabular}{|l|c|c|c|c|}
\hline & Pre final & Final & Post final 1 & Post final 2 \\
\hline 'fifths' fi & - & f & $\Theta$ & s \\
\hline 'next' ne & - & k & s & t \\
\hline 'lapsed' læ & & p & s & t \\
\hline
\end{tabular}

From the explanation above, we may describe the English syllable as having the following maximum phonological structure. ${ }^{7}$

\begin{tabular}{|c|c|c|c|c|c|c|c|c|}
\hline $\begin{array}{l}\text { Pre- } \\
\text { initial }\end{array}$ & Initial & $\begin{array}{l}\text { Post- } \\
\text { initial }\end{array}$ & $\begin{array}{c}\text { VOWEL/ } \\
\text { NUCLEUS }\end{array}$ & $\begin{array}{l}\text { Pre- } \\
\text { final }\end{array}$ & Final & $\begin{array}{c}\text { Postfinal } \\
1\end{array}$ & $\begin{array}{c}\text { Postfinal } \\
2\end{array}$ & Postfinal 3 \\
\hline \multicolumn{3}{|c|}{ ONSET } & & \multicolumn{5}{|c|}{ CODA } \\
\hline
\end{tabular}

Based of the explain above, the researcher concludes that the onset have three consonants cluster that is pre-initial, initial consonant, and post-initial consonant. Then the coda may consist of pre-final consonant, final consonant, and post final consonant.

\section{c. Types of syllables}

Many pronunciation problems result from ESL students' ability to produce the different syllable types of English. A consideration of this syllable types and how they differ from those of other languages will help in understanding these difficulties.

Some examples of the syllable types of English are provided below: ${ }^{8}$

$\begin{array}{lll}\text { Word } & \text { Transcription } & \text { syllable type } \\ \text { See } & {[\text { si: }]} & \text { C(consonant) V(owel) } \\ \text { Sit } & {[\text { sit }]} & \text { CVC }\end{array}$

\footnotetext{
${ }^{7}$ Ibid., p. 76.

${ }^{8}$ Peter Avery and Susan Ehrlich, Teaching American English Pronounciation, (New York: Oxford University Press, 1992), p. 53.
} 


$\begin{array}{lll}\text { Spit } & {[\text { spit }]} & \text { CCVC } \\ \text { Spits } & {[\text { spits }]} & \text { CCVCC } \\ \text { Sprint } & {[\text { sprint }]} & \text { CCCVCC }\end{array}$

The word 'see' has a CV syllable, the most common syllable type among the languages of the world. This is reffered to as an open syllable because it ends with a vowel. The word 'sit' has a CVC syllable, also common among the language of the world. This is reffered to as a closed syllable because in the ends with a consonant. The word 'spit' has a CCVC syllable with consonant cluster/sp/. The word 'spits' has a CCVCC syllable with consonant cluster at the beginning and the end. A consonant cluster at the beginning of a word is a final cluster. The word 'sprint' has a CCCVCC syllable. In this case the initial cluster has tree consonants and the final cluster his two consonants. ${ }^{9}$ The syllables types that is:

1) Closed syllable

Closed syllable have one vowel, followed by one or more consonant. The vowel has a short sound.

Example: in, on cat, him, pot, trash.

2) Open syllable

An open syllable ends in one vowel and the vowel says its name (long sounds). ${ }^{10}$

Example: me, so, I, fly, she, Flu

3) Vowel-consonant-E syllable (commonly known as silent E syllable)

In this syllable type, there is a vowel followed by a consonant and silent e. The silent e makes the vowel before it say its name (long sounds).

Example: hate, mile, hole, grape.

4) Vowel team syllable

This syllable type contains two vowels next to each other. The vowels make one sound about fifty percent of the time, this rule

\footnotetext{
${ }^{9}$ Ibid., p. 53.

${ }^{10}$ Peter Avery and Susan Ehrlich, Teaching American English Pronunciation, (New York: Oxford University Press, 1992), p. 53.
} 
will apply to double vowels: If two vowels go walking, the first one does the talking and says its name. The other vowel stays quiet. You can compare it to a bully. The first vowel shouts its name and the second one is quiet.

Examples: Wait, Beach, Beet, Play.

5) R-controlled syllable

In r-controlled syllable types, a vowel is followed by the letter $r$. The $r$ "controls" vowel, and gives it a different sound that is neither long or short.

Example :

Car, bar, tar: Ar sounds like the name of the letter R. You don't hear the $\mathrm{A}$ at all.

Er, ir, ur: Often sounds like ER as in her

Or sounds like the word or.

Any of the R controlled syllables (ar, er, ir, or, ur) can sound like ER when it appears at the end of words and is not accented.

Example : sailor, regular, grammar.

6) Consonant-le syllable

Consonant-le syllables are normally found at the end of a word. They consist of a consonant followed by the letters le. The le sounds like UL.

Example :tur/tle, lit/tle, sta/ble. ${ }^{11}$ So, consonant-le syllable followed letters le and we find at the end of a word.

\section{d. Rules of Syllable}

Every syllable has one vowel sound. The number of vowel sounds in a word equals the number of syllables.

1) When two or more consonants come between to vowels in a word, the word is usually divided between the first two consonants (don • key, sis • ter, but $\bullet$ ter, hun $\bullet$ gry).

\footnotetext{
${ }^{11}$ Ibid., p. 55.
} 
2) Consonant blends and diagraphs are never separated (rest • ting, bush • el, reach $\bullet$ ing).

3) When a word has a ck or an $\mathbf{x}$ in it, the word is usually divided after the ck or $\mathbf{x}($ nick $\bullet$ el, tax $\bullet$ i).

4) When a single consonant comes between two vowels in a word, it isusually divided after the consonant if the vowel is short $(\mathrm{lev} \bullet \mathrm{er}, \mathrm{cab}$ • in, hab • it).

Based on rules above, the researcher concludes that the rules for syllabification one syllable can not divided, if suffix and prefix devide the word between the base word the suffix and the prefix, when two or more consonant is usually divided between the first two consonants, a word has a ck or an $\mathbf{x}$ in it, the word is usually divided after the ck or $\mathbf{x}$, if a single consonant comes between two vowels in a word, it isusually divided after the consonant if the vowel is shortan long, and if two vowels come together in a word, and are sounded separately, divide the word between the two vowels.

\section{THE RESEARCH METHODOLOGY}

\section{The Place and Time of Research}

This research conducted in Institute for Islamic Studies (IAIN) Padangsidimpuan. It is located on Jl. H.Tengku Rijal Nurdin KM.4,5 Sihitang, Padangsidimpuan Selatan, Kotamadya Padangsidimpuan North Sumatera, Indonesia. This subject of the research is the sixth semester of TBI in IAIN Padangsidimpuan. Time of the research started on March 2017 until April 2017.

\section{Research Design}

Based on the analysis of data, this research used qualitative approach with descriptive method. Qualitative research is the research that's means to understand the phenomena about what is the subject research undergone by using natural method. ${ }^{12}$ Qualitative approach is based on the collection and analysis of non-numerical data such as observations, interviews, and other

\footnotetext{
${ }^{12}$ Lexy J. Moleong, Penelitian Kualitatif, (Bandung :Remaja Rosda karya, 2009), p. 126.
} 
more discursive sources of information. ${ }^{13}$ It means in qualitative non numerical data just describe phenomena.

Based on the method, this research used descriptive method. L. R. Gay said that descriptive research is a descriptive study determines and describes the way things are may also compare how subgroups such as males and females or experienced and inexperienced teachers view issues and topics. ${ }^{14}$ In other word qualitative research is not concerned simply with describing the way things, they also wish to provide insight into what people believe and feel about the way things.

Based on the explanation above, the researcher used Qualitative Descriptive Method to describe and analyzed the students' stressed syllables mastery at sixth semester of TBI in IAIN Padangsidimpuan.

\section{Sources of Data}

There were some sources that needed it in the research they are:

a. Primary sources of data are students sixth semester of TBI in IAIN Padangsidimpuan. They are TBI-4 classes. The informant of the research will be selected from TBI-4. They consist of 28 students. This research will be done by using purposive sampling; purposive sampling is a technique of taking sources of data with a certain judgment. ${ }^{15}$

b. Secondary data, the research collected the information from lecturer of TBI in IAIN Padangsidimpuan.

\section{Instrument of Collecting Data}

Sugiyono said that there are steps in collecting data of qualitative research include: test and interview. ${ }^{16}$ So to get an accurate data , The researcher of collecting data would be used in this research is:

8

${ }^{13}$ L. R Gay and Peter Airasian, Education Research, (USA :Printice Hall Incorporate, 2009), p.

${ }^{14}$ L. R. Gay and Peter Airasian, Educational Research: Competencies for Analysis and Application, (USA; New Jersey, 2000), p. 275.

${ }^{15}$ Sugiyono, Metode Penelitian Pendekatan Kuantitatif, dan $R \&$ D, (Bandung: Alfabeta, 2009), p. 300 .

${ }^{16}$ Ibid., p. 145 . 
a. Test

Test is one of the instrument that use in this research. The researcher will collecting the data use test. Brown defines "test as a method of measuring a person' ability; knowledge of performance in a given domain". ${ }^{17}$ It means, to know the ability, knowledge the performance of person we use test, this test can be written test and oral test. In this research the test that will be used is pronunciation test especially for stressed syllable. The test will be given to 28 students who become informant of the research. The informant will be tested true write stressed syllable in word pronunciation. The test is corrected in order to prove their mastery. This test used to describe students stressed syllables mastery and to find the students difficulties in pronunciation.

b. Interview

Hornby said interview is to talk somebody and ask his/her questions at a formal meeting to find out if he/she is suitable for job or study". ${ }^{18}$ Interview is a purposeful interaction usually between two people, focused on one person trying to get information from the other person. ${ }^{19}$ It means interview is a process where someone gives question to another person to get information about something need and another person that interview would given a response about the question.

This interview used to get the data of the reason students' stressed syllables mastery at sixth semester of TBI in IAIN Padangsidimpuan. The researcher interviewed students of TBI 4 the sixth semester to explain their problem in stressed syllables mastery. Then the researcher will interview the English lecturer he is Hamka, M.Hum to explain the students' stressed syllables mastery.

\footnotetext{
${ }^{17}$ H. Doughlas Brown, Language Assessment, (San Francisco Longman, 2004), p. 3.

${ }^{18}$ A. S. Hornby, Oxford Advenced Learner's Dictionary, (New York: Oxford University Press, 1995), p. 788.

${ }^{19}$ L. R. Gay and Peter Airasian, Educational Research, (USA: Printice Hall Incorporate, 2000), p. 8 .
} 


\section{Technique of Data Analysis}

In research, after collecting data, the researcher analyzed the data. The technique of data analysis will be presented in descriptive form. The researcher will analyze by using some steps. That are:

a. Identifying the students' stressed syllables mastery at sixth semester of TBI in IAIN Padangsidimpuan.

b. Finding problems of the students' stressed syllables mastery at sixth semester of TBI in IAIN Padangsidimpuan.

c. Talking about percentage of the data to calculated using the formula

$$
\mathrm{M}=\frac{\sum X}{\mathrm{~N}}
$$

$$
\begin{aligned}
& \text { Note }: \mathrm{M}=\text { mean score } \\
& \mathrm{N}=\text { sum of respondent } \\
& \sum X=\text { total of the result }
\end{aligned}
$$

d. Description of data, it is done do describe to interpreted data that have been collected systematically.

e. Finally, the researcher explain the reason given in interview as the conclusion from students. ${ }^{20}$

\section{E. CONCLUSION}

Based on the result after treating the collecting data, the next steps were taking the conclusions of this research. It is regarded important because it can be describe the final research itself. The conclusions of this research as following:

1. The students stressed syllables mastery at sixth semester of TBI in IAIN Padangsidimpuan was $68,92 \%$ and can be categorized good score. Based on the result found problems in one syllable with the score is 92,38 can be categorize very good. Two syllable with the score is 72,5 can be categorized good. Three syllable with the score is 67,14 can be categorized good and in four syllable with the score is 45 can be categorized enough.

\footnotetext{
${ }^{20}$ Anas Sudijono, Pengantar Statistik Pendidikan, (Jakarta:Raja Grafindo Persada, 1991), p. 43.
} 
2. Based on the result the data analysis the it appear that the students' stressed syllables mastery at sixth semester of TBI in IAIN Padangsidimpuan, particularyin English Education Department is low to stressed syllables mastery at sixth semester of TBI in IAIN Padangsidimpuan have a problem in transcription a word to the right syllable especially in nucleus (vowel sounds).

3. The result interview students the sixth semester of TBI IAIN Padangsidimpuan, the researcher concluded the difficulties of students when syllabifying English words is to transcript a word to the right syllable especially in nucleus (vowel sounds) because lack in practice syllabifying English words, low motivation, don't care when teacher explain the subject of syllable. The effort to solve it students enrich their practice about segment of phonemes that are vowel and consonant, Growing up the motivation students' stressed syllables mastery at sixth semester of TBI in IAIN Padangsidimpuan.

\section{REFERENCE}

Avery, Peter and Susan Ehrlich, Teaching American English Pronounciation. New York: Oxford University Press, 1992.

Carr, Philip, English Phonetic and Phonology: an introduction. USA : Blackwell publishers.

Creswell, John W. Research Design : qualitative, quantitative and mixed methods approaches. USA : Cambridge university press, 1990.

Collins, Baverly and Inger M. Mees, Practical Phonetic and Phonology. New York: First Published, 2009.

Gay, L. R. and Peter Airasian, Educational Research: Competencies for Analysis and Application. USA; New Jersey, 2000.

Giegerich, Heinz, J ,English Phonology An Introduction, Cambridge: University Press, 1992.

Hamka, Linguistic (An Introduction) Sekolah Tinggi Agama Islam Negeri (STAIN) Padangsidimpuan, 2011.

Hifni Marina Pade, The Students' Rising Intonation Ability of the Second Grade English Education Department IAIN Padangsidimpuan (Unpublished Script) (Padangsidimpuan IAIN 2015) 
Hornby, A.S. Oxford Advanced Learner's Dictionary of Current English. New York: Oxford University Press, 1995.

Jones, Daniel, An Outline of English Phonetics Cambridge: University Press,1975.

Katamba, Francis. An Introduction to Phonology, London and New York: Chee Leong Press Sdh,Bhd, 1992.

Lass, Roger, An Introduction to Basic Concepts, Cambridge: University Press, 1975.

Moleong, Lexy J. Penelitian Kualitatif. Bandung :RemajaRosdakarya, 2009.

Pourhossein Gilakjani, Abbas, English Language Department.Iran: Islamic Azad University,2011.

Riduan, Belajar Mudah Penelitian untuk Guru-Karyawan dan Peneliti Pemula.Bandung: Alfabeta, 2005.

Rini Erminawati, The influence of Mother Tongue to Students' Pronunciation(Unpublished Script) (Padangsidimpuan STAIN,2012).

Roach, Peter, English Phonectics and Phonology, a Practical Course. New York:Cambridge University Press, 1983.

Sudijono, Anas, Pengantar Statistik Pendidikan, Jakarta:Raja Grafindo Persada, 1991.

Sugiyono, Metode Penelitian Kuantitatif Kualitatif dan $R$ \& D. Bandung: Alfabeta, 2009.

Tracey Elen Taylor, "the effect of teaching two syllable types and one syllabication rule on the spelling achievement on the students with learning disabilities" (script the graduate faculty at Grand Valley State University, 1997).http://scholarworks.gvsu.edu/theses/391/pdf, accessed at 30 ,March, 2016 retrieved on $5 \mathrm{pm}$.

Trinh, Daniel, "the role of phonological syllable in English word recognition".(script the university of western Ontario, 2014). http://www.psychology.uwo.ca/faculty/lupker/conferences/presentations2013/tri nh.pdf, accessed at 3 ,January, 2017 retrieved on 5 pm. 